Для цитирования: Гарай Альварес Г.Р., Бертот Вальдес Х., Перес-Теруэль К. Интернет вещей для оценки поведения крупного рогатого скота при поиске корма и кормлении в пастбищных системах земледелия: концепции и обзор сенсорных технологий. Труды ИСП РАН, том 31, вып. 2, 2019 г., стр. 137-152 (на английском языке). DOI: 10.15514/ISPRAS-2019-31(2)-10

\section{Internet of Things for evaluating foraging and feeding behavior of cattle on grassland-based farming systems: concepts and review of sensor technologies}

${ }^{1}$ G.R. Garay Alvarez, ORCID: 0000-0002-2216-2436<godofredo.garay@reduc.edu.cu> J.A. Bertot Valdés, ORCID: 0000-0003-1562-6754<jose.bertot@reduc.edu.cu > ${ }_{3}^{3}$ K. Perez-Teruel,ORCID: 0000-0003-2154-3111< karinaperez@uapa.edu.do >

'Department of Informatics, University of Camaguey, Camaguey, Cuba ${ }^{2}$ Veterinary Department, University of Camaguey, Camaguey, Cuba. Universidad Abierta para Adultos UAPA, Av. Hispanoaméricana \#100, Santiago, República Dominicana.

Abstract. In this paper, we give an overview of the movement, foraging and feeding ecology as well as sensors technologies that could be embedded into an IoT-based platform for Precision Livestock Farming (PLF). A total of 43 peer-reviewed journal papers indexed by Web of Science were surveyed. Firstly, sensors technologies (e.g., RFID, GPS, or Accelerometer) used by the authors of each paper were identified. Then, papers were classified according to their applicability to ecological studies in the fields of foraging and feeding behavior.

Keywords: Internet of Things; IoT, sensors; precision agriculture; precision livestock farming

For citation: Garay Alvarez G.R., Bertot Valdés J.A., Perez-Teruel K. Internet of Things for evaluating foraging and feeding behavior of cattle on grassland-based farming systems: concepts and review of sensor technologies. Trudy ISP RAN/Proc. ISP RAS, vol. 31, issue 2, 2019. pp. 137-152. DOI: 10.15514/ISPRAS2019-31(2)-10

Acknowledgments. This work is partially supported by VLIR-UOS, Belgium.

\section{Интернет вещей для оценки поведения крупного рогатого скота} при поиске корма и кормлении в пастбищных системах земледелия: концепции и обзор сенсорных технологий

${ }^{1}$ Г.Р Гарай Альварес, ORCID: 0000-0002-2216-2436<godofredo.garay@ reduc.edu.cu>

${ }^{2}$ X. Бертот Вальдес, ORCID: 0000-0003-1562-6754<jose.bertot@reduc.edu.cu>

${ }^{3}$ K. Перес-Теруэль, ORCID: 0000-0003-2154-3111<karinaperez@uapa.edu.do>

' Факультет информатики, Университет Камагуэй, Куба

${ }^{2}$ Факультет ветеринарии, Университет Камагуэй, Куба

${ }^{3}$ Открытый университет для взрослых, Сантьяго, Доминиканская Республика

Аннотация. В этой статье приводится обзор экологических аспектов перемещения, кормодобывания и кормления крупного рогатого скота, а также технологий датчиков, которые могут быть встроены в основанную на Интернете вещей платформу для поддержки точного животноводства. Всего были проанализированы 43 рецензированных журнальных статьи, проиндексированные Web of Science. Boпервых, были идентифицированы сенсорные технологии (например, RFID, GPS или акселерометр), используемые авторами каждой статьи. Затем документы были классифицированы в соответствии с их применимостью к экологическим исследованиям в области кормодобывания и кормления скота.
Благодарности. Эта работа поддерживается VLIR-UOS, Бельгия.

\section{Introduction}

The Internet of Things (IoT) is a paradigm where every-day objects can be equipped with identifying, sensing, networking and processing capabilities that will allow them to communicate with one another and with other devices and services over the Internet to accomplish some objective [1].

In Precision Livestock Farming, IoT is extended to farm animals, i.e., real-time monitoring technologies aimed at managing the smallest manageable production unit's temporal variability. This approach is known as 'the per animal' [2].

For ecologists, understanding the reaction of animals to environmental changes is critical. Using networked sensor technology to measure wildlife and environmental parameters can provide accurate, real-time and comprehensive data for monitoring, research, and conservation of wildlife [3], [4]

The scientific motivation of our review is to provide a comprehensive summary of the rapidly developing area of sensors technologies for Precision Livestock Farming (PLF) from an IoT perspective. The survey seeks to encourage computer scientists to conduct transdisciplinary research in the field of veterinary computer sciences/veterinary sciences.

In this paper, we give an overview of the movement, foraging and feeding ecology as well as sensors technologies that could be embedded into an IoT-based platform for Precision Livestock Farming (PLF). A total of 43 peer-reviewed journal papers indexed by Web of Science were surveyed. Firstly, sensors technologies (e.g., RFID, GPS, or Accelerometer) used by the authors of each paper were identified. Then, papers were classified according to their applicability to ecological studies in the fields of foraging and feeding behavior.

The paper is organized as follows. We first motivate the need for an IoT-based collection of movement and behavior data from the perspective of PLF. In addition, background information on ecology is given (Section 2). We then present a level-based approach for conducting the review (Section 3) and a classification of the literature based on such approach (Section 4). Next, we discuss some potential areas of transdisciplinary research (Section 5) and finally provide concluding remarks (Section 6).

\section{Background}

\section{1 loT-based platform for livestock farming}

Detailed observation of the movement and behavior of animals at pasture offers the potential to understand spatial population processes as the ultimate consequence of individual behavior, physiological constraints and fine-scale environmental influences such as heat stress [5], [6], [7] [8].

Fig. 1 illustrates the integrated framework for farm management decision-making considered in this paper. It consists of four main phases: a collection of animal movement data using IoT sensors, transfer of data using communication technologies, analysis \& planning conducted by data managers, and, finally, decision-making. Particularly, in this paper, we focus on collecting animal movement and behavior data on grassland-based farms. 


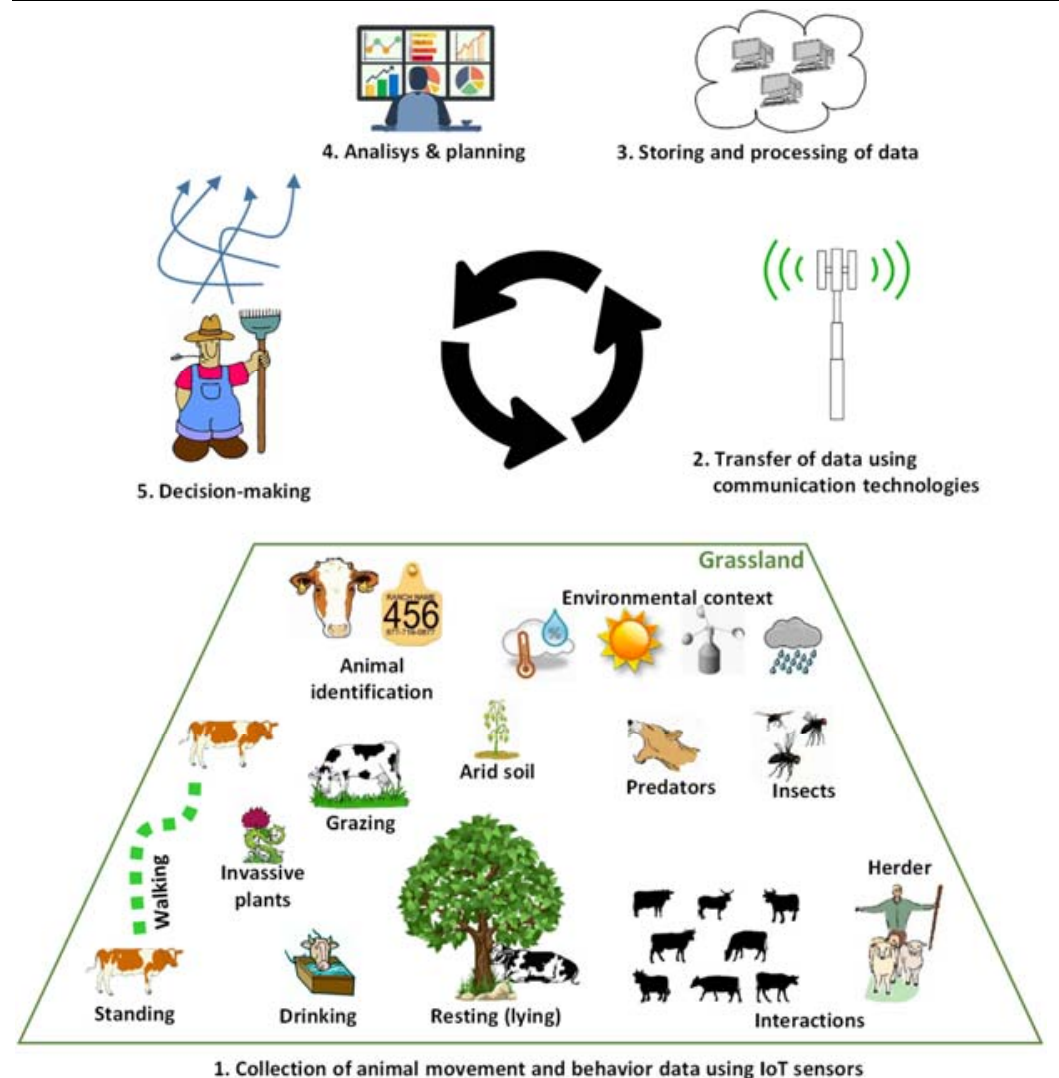

1. Collection of animal movement and behavior data using loT sensors

Рис. 1. Иллюстрачия ІоТ-экосистемы для точного животноводств

Fig. 1. Illustration of IoT Ecosystem for Precision Livestock Farming

\subsection{Animal ecology}

Ecology is the scientific study of the interactions of organisms with the environment that determine their distribution and abundance. The environment of an organism consists of all those factors and phenomena that can influence it, whether those factors be physical and chemical (abiotic) or other organisms (biotic). Biotic means living, and biotic factors are the other, living parts of the ecosystem with which an organism must interact (e.g., predators, invasive plants, etc.). Abiotic means a nonliving condition or thing, as climate or habitat, that influences or affects an ecosystem and the organisms in it, (e.g., arid soils). In animal ecology, every scientific problem resolves itself into a quest for the relationship between two or more variables. The discovery of these inter-relations provides the basis for prediction and control [9]

\subsubsection{Movement Ecology}

In the context of movement ecology, movement of an organism is defined as a change in the spatial location of the whole individual in time [9]. Animal positions data provide the elemental unit of movement paths and show where individuals interact with the ecosystems around them. The movement paths of animals over landscapes are represented by sequences of points (xi, yi) occurring at times ti. Modeling animal movement from spatiotemporal data is generally performed using two approaches, i.e., (i) the Lagrangian approach and (ii) the Eulerian approach [10]. The Lagrangian approach is individual-based and entails tracking a specific individual, while the Eulerian approach is place-based and deals with the probability of the presence of an individual or a group in a place and the change of this occurrence over time. Movement metrics are quantities that might be calculated directly from raw, uncorrected and unprocessed movement data. These metrics can be grouped into two large categories: trajectory analysis metrics and space-use analysis metrics [11] For describing the path, the most basic ones are the step length (the Euclidean distance between consecutive relocations) and turning angle (the angle of one step relative to the step immediately prior), and the distance traveled by animals [12]. Such distance is an important ecological variable that links behavior, energetics, and demography. It is usually measured by summing straight-line distances between intermittently sampled locations along continuous animal movement paths [13]. On the other hand, the space-use analysis is based on spatial data types. These data types define points, lines, areas, and volumes. To measure the spatiotemporal change in a field population of individuals, the population may often be sampled in two-dimensional space on a series of occasions. The spatial pattern of data is usually shown in the form of maps where the two-dimensional coordinates of every individual are recorded. In animal ecology, spatial data are often recorded as counts of the number of individuals occurring in each of several sample units, where the location of each unit is known [14].

In this review, movement ecology metrics are the basis for the rest of the subdisciplines shown below.

\subsubsection{Foraging Ecology}

How animals search for their food arguably represents one of the most important aspects of foraging ecology. Grazing behavior is an important process directly associated with animal nutrition intake, fitness, and productivity [15], [16]. Ruminants are mammals that have a unique digestive system that allows them to better use energy from fibrous plant material than other herbivores. The ruminan digestive system uniquely qualifies ruminant animals such as cattle to efficiently use high roughage feedstuffs, including forages. Monitoring the specific behaviors of ruminants, particularly grazing and rumination, is important because these behaviors occupy much of the grazing cattle's timebudget [17]. Ruminant activity is an important index reflecting the health of animals with rumens When cows suffer from the disease, rumination time decreases significantly. The influence of a variety of diseases affects the rumination time uniquely.

In general, animal's states can be classified into sub-classes according to different standards and purposes. Following the classification suggested in [18], the state classes we are using are shown in Fig. 2.

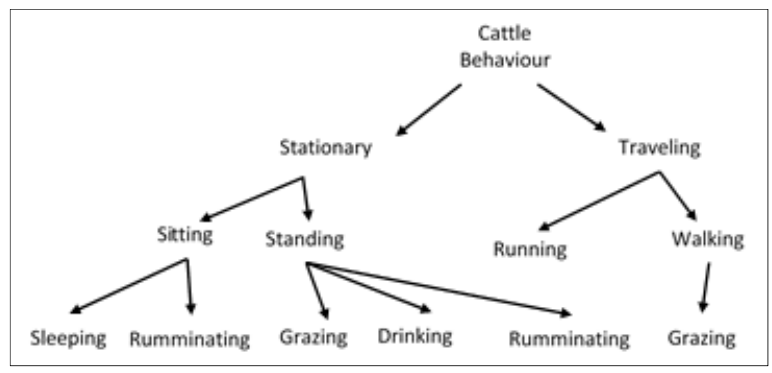

Рис. 2. Классы поведения скота

Fig. 2. Classification of cattle behavior classes 
A better understanding of how cattle behave can be obtained with the help of fine spatiotemporal scales. For example, the provision of shade to cows under heat stress conditions is an essential component of heat management animals ruminating [19]

\subsubsection{Feeding Ecology}

Central to the study of animal ecology is how the environment is used by an animal: specifically, the kinds of foods it consumes and the varieties of habitats it occupies. We define habitats as regions in environmental space that are composed of multiple dimensions, each representing a biotic or abiotic environmental variable; that is, any component or characteristic of the environment related directly (e.g., forage biomass and quality) or indirectly (e.g., elevation) to the use of a location by the animal. Environmental variables can be dynamic or static (e.g., predator density and slope, respectively) and may be positively or negatively associated with use. Habitat use is the proportion of their time that animals spend in a particular habitat [20], [21].

The abundance of a component is the quantity of that component in the environment, as defined independently of the consumer. The availability of that component is its accessibility to the consumer. The usage of a component by the consumer is the quantity of that component utilized by the consumer in a fixed period. The selection of a component is a process in which an animal chooses that component. Usage is said to be selective if components are used disproportionately to their availability. The preference of a consumer for a particular component is a reflection of the likelihood of that component being chosen if offered on an equal basis with others. In theory, components can be ranked from "most preferred" to "least preferred." [21]. That what the animals select to eat given a set of physical constraints can be defined as 'selection.' For example, animals offered a sward containing grass and clover in an intimate mixture have to search through the mixture to find their preferred herbage. This requirement to search imposes a constraint on the animal's ability to eat what it wants, so is an example of selection [22]. Intuitively, animals should distribute themselves according to the quality of habitats. If the selection is consistent with fitness, we should find more animals in better-quality habitats [23]

\section{Planning the review}

Fig. 3 illustrates the flow of this section. Three levels of information are provided: animal level offers brief information on animals considered in the context of this paper, IoT elements level provides an overview on IoT sensors, and finally, Ecology levels focus on the application of sensor technologies for ecological studies.

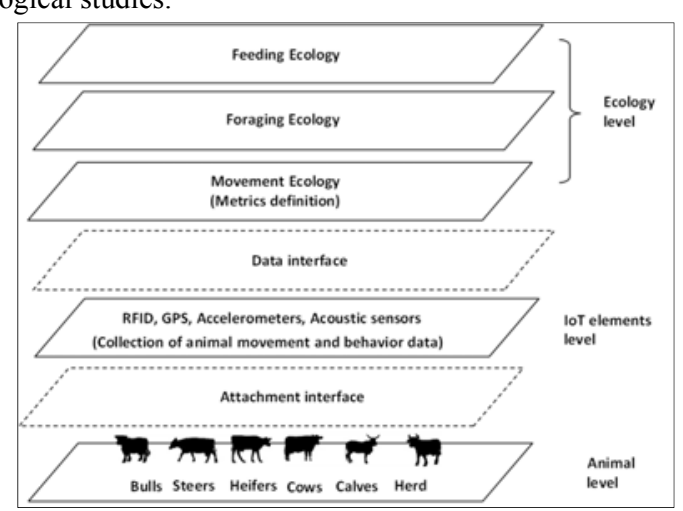

Рис. 3. Концептуальная структура анализа литературы Fig. 3. The conceptual framework for the literature analysis

\subsection{Animal level}

Cattle are social animals. They live in large groups, called herds. A herd may consist of just a single or several cattle families. A bull is a mature male animal that is used for breeding. A steer is a castrated male calf raised for beef. A dominant male (bull) guards a group of females (cows) and their young (calves) protectively. A heifer is a female animal that has never had a calf. Once a heifer has a calf, she automatically becomes a cow.

\section{2 loT level}

Radio Frequency Identification (RFID). Cattle identification and tracking refer to the process of accurately recognizing individual cattle and their products via a unique identifier or marker. Animal identification plays an influential role in understanding disease trajectory, vaccination and production management, animal traceability, and animal ownership assignment. Classical cattle identification systems can be grouped into three categories: permanent methods (e.g., ear notching, ear tattooing, etc.), temporary methods, and electrical methods [24]. The RFID technology is a breakthrough in the embedded communication paradigm which enables the design of microchips for wireless data communication. They help in the automatic identification of anything they are attached to acting as an electronic barcode. The passive RFID tags are not battery powered. They use the power of the reader's interrogation signal to communicate the ID to the RFID reader. Radio frequency identification (RFID) tags can be activated by a specific radiofrequency to send location information to a receiver. A passive RFID tag does not need any power source because it produces needed energy by an antenna. The reading distances can be a few meters. The tracking system can also work so that the moving objects have RFID tags and when a tag is close enough to a reader, the location is measured. The RFID technology is usually used like this for animal identification. The tracking resolution depends on the number of readers and the reading distance [25].

Accelerometry. Remote sensors, such as accelerometers, can monitor the behavior of animals constantly. These devices are small, relatively low-cost and noninvasive. Accelerometers should not influence the natural behavior patterns of animals in free-living conditions. An accelerometer detects bodily acceleration, which is represented as an analog voltage created by a piezoelectric instrument that is sensitive to compression in a vertical direction. Different types of devices are available and the choice about which to use depends on various factors: cost (especially when large population are studied), physical characteristics (weight, size, and battery life), performance (number of axes, possible epochs, system of data transfer, recording duration, function of the epochs, and the memory capacity), and the validity and intra- and inter-instrument reliability [26], [27]. It is worth noting that according to the number of axes, accelerometers can be classified in uniaxial, two-axil or tri-axial devices (a.k.a. unidimensional (1D), two-dimensional (2D) and tri-dimensional (3D), respectively). The tri-axial acceleration data is of specific interest as it provides quantitative data on body posture and motion. The three axes of the accelerometer are aligned to the dorso-ventral axis, the anteriorposterior axis and the lateral axis of the subject animal. These are termed (in biological parlance) heave, surge and sway respectively. These axes are analogous to the $\mathrm{Y}, \mathrm{Z}$, and $\mathrm{X}$ axes in cartesian coordinates [27] (fig. 4)

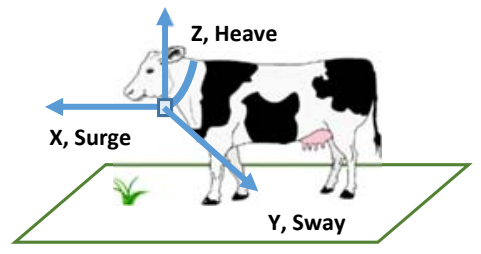

Рис. 4. Схема коровы с нашейным датчиком Fig. 4. Schematic of cow with a collar 
Global Positioning System. Today, the majority of movement ecology research depends upon more advanced satellite technology, referred to broadly as Global Positioning Systems (GPS), to record
a advanced satellite technology, referred to broadly as Global Positioning Systems (GPS), to record
animal locations at finer spatial and temporal resolutions. Global Positioning System (GPS) units derive positions from internal receivers monitoring signals from an array of 24 earth-orbiting [28]. Radio-collars and other sensors equipped with global positioning systems (GPS) allow providing a continuous record of animal locations (a.k.a relocations) that remains unobtainable using traditional is based on receiving track and time mark signals from satellites and calculating a receiver location based on distances to satellites.

Acoustic sensors. Eating and ruminating last for a considerable period and account for most of a ruminant's daily activity. The direct and continuous observation of these activities is labor-intensive, time-consuming, and frequently not feasible. These difficulties have promoted the development of automatic recording devices. Regurgitation and rumination produce distinctive sounds that are recorded by a microphone, processed, digitally stored. The method allows accurate counts of ruminant bites, chews, and complex chew-bite events. Acoustic monitoring can be carried out offline (i.e., restricted to desktop computers) or in real-time [29], [30]. Acoustic sensors can be found as independent devices on the market (e.g. [31] or embedded into accelerometer devices.

\subsection{Interfaces}

Attaching measuring devices to animals is often the only way to acquire vital life-history information on species that do not lend themselves to observation. However, the ethics of acceptable practice for attached devices are poorly defined. Here, we consider the need for further research and attempt to identify a system that allows animal restraint practices and device-induced effects to be quantified and monitored so that ethics committees can have a defined scale on which to base decisions [32]. In general, sensors here reviewed can be attached to different parts of the animal body, e.g., legs, neck, and ears. Miniaturized sensors play a significant role in ecology-related researches. In the seminal paper by (Ungar et al., 2005), cows were fitted with leg-attached GPS collars weighing about $1.15 \mathrm{~kg}$ [33]. Nowadays, GPS collars are commonly used. It should be noted that many sensors are dataloggers; hence, handing animal is needed for retrieving data.

\section{Classification of literature}

The literature was classified according to its content into the following major categories: Movement Ecology, Foraging Ecology, and Feeding Ecology. Some of these top-level categories were further broken down into sub-categories.

\subsection{Movement Ecology}

A variety of global positioning system tracking collars for use on cattle has been developed. In general, these collars can be manufactured by companies or custom-built. According to [34], the effect of GPS sample interval and paddock size on estimates of distance traveled by grazing cattle in rangeland is an important issue to consider.

The number of animals required to represent the collective characteristics of a group remains a concern in animal movement monitoring with GPS. Monitoring a subset of animals from a group instead of all animals can reduce costs and labor; however, incomplete data may cause information losses and inaccuracy in subsequent data analyses. In cattle studies, little work has been conducted to determine the number of cattle within a group needed to be instrumented considering subsequent analyses. In [35], a characterization of cattle movement is conducted. Metrics for analyzing herd movements, such as average herd travel speed, daily travel distances, average herd radius, average centroid location deviation, and average herd radius deviation, are considered. In [36], it is evaluated how closely do collared animals cluster in their herd and how well do different logging intervals affect estimations of total distance traveled by collared animals.

\subsection{Foraging ecology}

Animal behavior such as, walking, foraging, standing, lying, can be derived from high-frequency GPS. This approach allows tracking cows in open and forested habitat [37], [38], [39]. Spatiotemporal patterns of cattle grazing were studied in four annual grassland pastures in North America differing mainly in tree canopy cover. Cows were equipped with global positioning collars that recorded position, temperature and head movements at 5-min intervals during six days in each of four seasons repeated during two years. The time animals took to traverse areas of varying diameter revealed patches of 6-9-m diameter in the pastures with low, and 18-21-m diameter in the pastures with high tree canopy cover [40]. The authors of [41] analyze a high-frequency movement dataset for a group of grazing cattle and investigate their spatiotemporal patterns using a mobility model. In [42], the spatiotemporal dynamics of cattle behavior and resource selection patterns on East African rangelands. Based on the integration of GPS-tracking and field observations, this study links cattle behavioral types with statistical parameters of movement, analyzes spatiotemporal dynamics of behavior and predicts resource selection patterns.

In livestock farming, the accurate prediction of calving time is a key factor for profitability and animal welfare. Continuous monitoring systems can detect behavioral changes occurring on the actual day of calving, some of them being accentuated in the last few hours before delivery; standing/lying transitions, tail raising, feeding time, and dry matter and water intakes differ between cows with poor health conditions. Use of these behavioral changes has the potential to improve the management of calving [43].

In [44], a behavioral model of the pasture-based dairy cow that requires incoming, transformed GPS data collected from cattle to be partitioned into segments of a fixed length before behavioral classification into grazing, resting or walking. GPS data such as distance traveled $(\mathrm{m})$ and turning angle (degrees) were used by the developed model. In [45], GPS data collected over a 4-yr period on 52 crossbred young cows grazing a 146-ha pasture were used to determine whether cattle establish patch-scale rotational grazing patterns within pastures.

Distinguishing cattle foraging activities using accelerometry-based activity monitors is widely reported in the literature. For example, grazing behavior [46], lying, standing or walking [47], walking and standing [48], lying time and frequency of lying bouts [49], lying behavior [50], grazing, rest, travel [51]. In [52], an in-depth study of wireless sensor networks applied to the monitoring of animal behavior in the field is described. Herd motion data, such as the pitch angle of the neck and movement velocity, were monitored by a sensor equipped with a 2-axis accelerometer. In many studies, rumination is assessed by using accelerometers with acoustic sensors included. In [53], accelerometer systems have been validated for detecting rumination time, chewing cycles, and rumination bouts. Accelerometer data on cow activity and rumination have been used for improving prediction of the start of calving in dairy cows [54] as well as monitoring feeding behavior in feedlot cattle [55]. In [56], various supervised machine learning techniques were applied to classify cattle behavior patterns recorded using collar systems with 3-axis accelerometer, fitted to individual dairy cows to infer their physical behaviors. In [57], estimation of grass intake on pasture for dairy cows using tightly and loosely mounted di- and tri-axial accelerometers combined with bite count. In [58], the influence of breed, milk yield, and temperature-humidity index on dairy cow lying time, neck activity, reticulorumen temperature, and rumination behavior is assessed. In [59], cattle adaptation to heat stress is assessed. The movement, ruminating time and weight gain between 2 breeds kept for 80 days at pasture during tropical spring are compared. Animal motility (measured using an accelerometer) and rumination time (minutes/day, using a sound sensitive sensor) were evaluated through a collar-sensor by radio telemetry. Rumen temperature was recorded at $10 \mathrm{~min}$ intervals using RFID rumen temperature sensor. A 3-dimensional accelerometer is attached to the RFID ear 
tag, and an online application provided by the manufacturer records time spent feeding, ruminating, active, and resting per hour and per day. Raw data were transmitted every minute through radio active, and resting per hour and per day.
ZigBee-based frequency technology [57].

Other authors have assessed rumination and activity patterns by using accelerometers. For example, rumination, feeding, activity, and animal temperature [54], feeding, ruminating, active, and resting [55], rumination time, chewing cycles, and rumination bouts [53], lying time, neck activity, reticulorumen temperature, and rumination time [58], grazing, searching, ruminating, resting, and scratching [56], level of activity and rumination [60], grazing, ruminating, walking, resting behaviors to develop algorithms for pasture intake by individual grazing cattle [61], rumination and its relationship to feeding and lying behavior in Holstein dairy cows] [62]. In [63], GPS locations were recorded to calculate mean slope, elevation, distance from water, distance traveled per day, and elevation for each cow.

Relationships between ambient conditions, thermal status, and feed intake of cattle during summer heat stress with access to shade. Ear tags, telemetrically connected to a feed monitoring system, provided animal data using RFID technology. Data loggers recorded ambient conditions in the sun and shade, along with black globe temperature [64]. The authors of [40] hypothesize that when forage is of low quality and abundant, animals will fill up faster and tend to travel shorter distances while grazing, thus imposing greater heterogeneity of forage utilization. GPS collars were programmed to record a position every $5 \mathrm{~min}$ for each one-week grazing period. Collars recorded longitude, latitude, date, time, elevation, temperature, forward-backward collar movement, leftright collar movement and satellite ephemeris information. Data were downloaded from the collars following each grazing period and differentially corrected by removing the positional error recordec by a stationary 'base' unit whose true coordinates were known. Authors conclude that shade distribution can modulate meal start and duration. [65] investigates the direct effects of tightly bunched herding versus loosely bunched herding on foraging behavior, nutrition, and performance (weight gain) of cattle in semiarid savanna rangeland. To this end, the mean daily distance covered by the herds under study are quantified.

\subsection{Feeding ecology}

To understand the spatial extent of grazing bouts and to determine the speed at which the animals were moving, the authors of [66] record GPS coordinates at the start and end of each feeding bout to determine the distance covered by the herd. In the conducted experiments, feeding ecology of four livestock species under different management in a semi-arid pastoral system is assessed. In [67], the development of a threshold-based classifier for real-time recognition of cow feeding and standing behavioral activities from accelerometer data is presented. In [68], the use of sensors combining local positioning and acceleration is used to measure feeding behavior differences associated with lameness in dairy cattle. It is worth noting that cattle lameness is one of the most significant welfare and productivity issues in dairy farming. That is why, to asses lameness by visual methods, a 5-point lameness scoring system that assessed gait and back posture has been developed (see [69]). In [57], estimation of grass intake on pasture for dairy cows using tightly and loosely mounted di- and tri-axial accelerometers combined with bite count are carried out. In [70], determination of minimum meal interval and analysis of feeding behavior in shaded and open-lot feedlot heifers as conducted by using RFID technology.

In [71], GPS units are deployed to monitor cattle movements and habitat use and to assess the impact of cattle grazing on vegetation. In [72], GPS data were used to quantify the movement patterns of elephant bulls, buffalo and cattle at multiple scales and according to seasonal changes of surface water availability. In [73], space use and movement trajectory statistics are assessed to We identify site fidelity patterns in animal location data.

Electronic radio-frequency-identification-based systems can be used for measuring: feeding behavior traits in beef cattle [74,75]; factors affecting water intake of growing beef cattle [62]; feeding time and dry matter intake (DMI) by recording each time each cow placed her head into the feed bin, and calculated the total duration of the feeder visit as well as the amount of feed consumed feed bin, and calculated the total duration of the feeder visit as well as the amount of feed consumed
during that visit. In [76], RFID-based system for monitoring individual feeding and drinking behavior and intake in young cattle is validated. In [77], RFID technology is used to record grazing beef cattle water point use.

\subsection{Summary}

In Table 1, based on the subdisciplines of Ecology shown in Section 2, we summarize the studies published in the literature. We want to note that the scope of some is not limited to a single category. For example, [40] studies aspects of the three subdisciplines here reviewed while [55], [57], [64] [68] address only aspects of foraging and feeding ecology.

Табл, 1. Классификаиия статей, рассмотренных в подразделах 4.1-4.3. Table 1. Classification of the reviewed papers in Subsections 4.1-4.3

\begin{tabular}{|c|c|c|c|}
\hline $\begin{array}{l}\text { Major } \\
\text { category }\end{array}$ & GPS & RFID & Accelerometer \\
\hline $\begin{array}{l}\text { Movement } \\
\text { Ecology }\end{array}$ & $\begin{array}{l}\text { [40], [63], [34], } \\
{[35],[36],[44],} \\
{[65],[66]}\end{array}$ & & \\
\hline $\begin{array}{l}\text { Foraging } \\
\text { Ecology }\end{array}$ & $\begin{array}{l}\text { [37], [38], [39], } \\
{[40],[41],[42],} \\
{[43],[44],[46],} \\
{[47],[48],[78],} \\
{[50],[51],[66],} \\
{[67],[69]}\end{array}$ & [64], [68] & $\begin{array}{l}{[52],[53],[54],} \\
{[55],[56],[57],} \\
{[58],[59],[60],} \\
{[61]}\end{array}$ \\
\hline $\begin{array}{l}\text { Feeding } \\
\text { Ecology }\end{array}$ & $\begin{array}{l}\text { [40], [42], [43], } \\
{[63],[64],[65],} \\
{[69],[70]}\end{array}$ & $\begin{array}{l}\text { [61], [64], [68], } \\
{[71],[72],[73],} \\
{[74],}\end{array}$ & {$[55],[57],,[61]$} \\
\hline
\end{tabular}

\section{Discussion}

Rapid advances in technology are allowing scientists to use data-recording units to acquire huge, quantitative datasets of behavior from animals moving freely in their natural environment. For analyzing animal movement data, a number of $\mathrm{R}$ software packages have been developed, e.g., moveHMM [79], ctmm [80], feedr and animalnexus.ca [81], trajr [82].

Data-driven agriculture involves the collection of enormous, dynamic, complex and spatial data which requires storage and processing. Great gains can be made by sharing online and exchanging animal tracking data. Two examples are: (1) Movebank project [83], [84], and (2) OzTrack project, [85]. Cloud-based data storage or farm-based storage can be considered for storing data. The use of cloud IoT platforms allows for big data collected from sensors to be stored in the cloud.

The ultimate goal is to suggest managerial options to the farmer. Specialized grassland management techniques allow farmers to improve the decision-making process by applying sound principles and guidelines for managing cattle grazing in the grazing lands [86]. To this end, behavioral models for a pasture-based dairy cow from GPS data can be developed. These models can use, for example, data mining, machine learning techniques [87], or Markov models [44].

Foraging activities and questions of energy optimization are difficult to quantify in practice, but recent advances in Geographic Information Systems (GIS) and Global Positioning Systems (GPS) have a greatly simplified examination of many spatially related phenomena. 
From the hardware viewpoint, custom-built, open-source GPS datalogger based on Arduino for collecting data can be designed and built (see [36]).

\section{Conclusions}

This paper has reviewed the literature on sensors in livestock farming and provides an overview of existing applications. The review shows that the subject received a lot of attention from the scientific community. The value of technology can be best realized when integrated with agronomic knowledge, using the information gathered in the improvement of decision support systems.

Both computer science scientists and veterinary science scientists can use the information here provided for conducting transdisciplinary researches.

\section{References}

[1]. Whitmore, A., Agarwal, A., Xu, L.D. The Internet of Things - A survey of topics and trends. I Information Systems Frontiers, vol. 17, no. 2, 2015, pp. 261-274.

[2]. Halachmi, I., Guarino, M. Editorial: Precision livestock farming: a 'per animal' approach using advanced monitoring technologies. Animal, vol. 10, no. 9, 2016, pp. 1482-1483.

[3]. Guo S., Qiang M., Luan X., Xu P., He G., Yin X., Xi L., Jin X, Shao J, Chen X, Fang D., Li B. The application of the Internet of Things to animal ecology. Integrative zoology, vol. 10, no. 6, 2015, pp. 572578

[4]. Ingrand S. Opinion paper: 'monitoring te salutant:' combining digital sciences and agro-ecology to design multi-performant livestock farming systems. Animal, vol. 12, no. 1, 2018, pp. 2-3.

[5]. Nathan R., Getz W.M., Revilla E., Holyoak M., Kadmon R., Saltz D., Smouse P. E. A movement ecology paradigm for unifying organismal movement research. Proceedings of the National Academy of Sciences, vol. 105, no. 49, 2008, pp. 19052-19059.

[6]. Getz W.M., \& Saltz D.A framework for generating and analyzing movement paths on ecological landscapes. Proceedings of the National Academy of Sciences, vol. 105, no. 49, 2008, pp.19066-19071.

[7]. Lallo C. H., Cohen J., Rankine D., Taylor M., Cambell J., \& Stephenson T. Characterizing heat stress on livestock using the temperature humidity index $(\mathrm{THI})$ - prospects for a warmer Caribbean. Regional Environmental Change, vol. 18, no. 8, 2018, pp.1-12.

[8]. Polsky L., \& von Keyserlingk M.A. Invited review: Effects of heat stress on dairy cattle welfare. Journal of dairy science, vol. 100, no. 11, 2017, pp. 8645-8657.

[9]. Nathan R., Getz W.M., Revilla E., Holyoak M., Kadmon R., Saltz D., \& Smouse P.E. A movement ecology paradigm for unifying organismal movement research. Proceedings of the National Academy of Sciences, vol. 105 , no. 49, 2008, pp. 19052-19059.

10]. Smouse P.E., Focardi S., Moorcroft P.R., Kie J.G., Forester J.D., \& Morales J.M. Stochastic modelling of animal movement. Philosophical Transactions of the Royal Society B: Biological Sciences, vol. 365, no. 1550, 2010, pp. 2201-2211.

[11]. Seidel D.P., Dougherty E., Carlson C., Getz W.M. Ecological metrics and methods for GPS movement data. International Journal of Geographical Information Science, vol. 32, no. 11, 2018, pp. 2272-2293.

[12]. Dougherty E.R., Seidel D.P., Carlson C. J., Spiegel O., \& Getz W.M. Going through the motions: incorporating movement analyses into disease research. Ecology letters, vol. 21, no. 4, 2018, pp. 588-604

13]. Marcus Rowcliffe J., Carbone C., Kays R., Kranstauber B., \& Jansen P. A. Bias in estimating animal trave distance: the effect of sampling frequency. Methods in Ecology and Evolution, vol. 3, no. 4, 2012, pp.
$653-662$.

[14]. Perry J.N., Liebhold A.M., Rosenberg M.S., Dungan J., Miriti M., Jakomulska A., \& Citron-Pousty S Illustrations and guidelines for selecting statistical methods for quantifying spatial pattern in ecological data. Ecography, vol. 25, no. 5, 2002, pp. 578-600.

[15]. DelCurto T., Porath M., Parsons C.T., \& Morrison J.A. Management strategies for sustainable beef cattle grazing on forested rangelands in the Pacific Northwest. Rangeland Ecology \& Management, vol. 58, no. 2, 2005, pp. 119-127.

16]. Sanon H.O., Kaboré-Zoungrana C., \& Ledin I. Behaviour of goats, sheep and cattle and their selection of browse species on natural pasture in a Sahelian area. Small Ruminant Research, vol. 67, no. 1, 2007, pp. 64-74.
17]. Kilgour R.J. In pursuit of "normal": A review of the behaviour of cattle at pasture. Applied Animal Behaviour Science, vol. 138, no. 1-2, 2012, pp. 1-11

[18]. Guo Y., Corke P., Poulton G., Wark T., Bishop-Hurley G., \& Swain D. Animal behaviour understanding using wireless sensor networks. In Proc. of the 31st IEEE Conference on Local Computer Networks, 2006 pp. 607-614.

[19]. Polsky L., \& von Keyserlingk M.A. Invited review: Effects of heat stress on dairy cattle welfare. Journal of dairy science, vol. 100, no. 11, 2017, pp. 8645-8657.

[20]. Beyer H.L., Haydon D.T., Morales J.M., Frair J.L., Hebblewhite M., Mitchell M., \& Matthiopoulos J. The interpretation of habitat preference metrics under use-availability designs. Philosophical Transactions of the Royal Society B: Biological Sciences, vol. 365, no. 1550, 2010, pp. 2245-2254.

[21]. Johnson D.H. The comparison of usage and availability measurements for evaluating resource preference. Ecology, vol. 61, no. 1, 1980, pp. 65-71.

[22]. Rutter S.M. Diet preference for grass and legumes in free-ranging domestic sheep and cattle: current theory and future application. Applied Animal Behaviour Science, vol. 97, no. 1, 2006, pp.17-35.

[23]. Johnson C.J., \& Seip D.R. Relationship between resource selection, distribution, and abundance: a test with implications to theory and conservation. Population Ecology, vol. 50, no. 2, 2008, pp. 145-157.

[24]. Awad A.I. From classical methods to animal biometrics: A review on cattle identification and tracking. Computers and Electronics in Agriculture, vol. 123, 2016, pp. 423-435.

[25]. Huhtala A., Suhonen K., Mäkelä P., Hakojärvi M., \& Ahokas J. Evaluation of instrumentation for cow positioning and tracking indoors. Biosystems Engineering, vol. 96, no. 3, 2007, pp. 399-405.

[26]. Vanhelst J., Béghin L., Duhamel A., Bergman P., Sjöström M., \& Gottrand F. Comparison of uniaxial and triaxial accelerometry in the assessment of physical activity among adolescents under free-living conditions: the HELENA study. BMC medical research methodology, vol. 12, no. 1, 2012

[27]. Grundy E., Jones M.W., Laramee R. S., Wilson R.P., \& Shepard E.L. Visualisation of sensor data from animal movement. In Computer Graphics Forum, vol. 28, no. 3, pp. 815-822.

[28]. Frair J.L., Fieberg J., Hebblewhite M., Cagnacci F. DeCesare N.J. \& Pedrotti L. Resolving issues of imprecise and habitat-biased locations in ecological analyses using GPS telemetry data. Philosophical Transactions of the Royal Society B: Biological Sciences, vol. 365, no. 1550, 2010, pp. 2187-2200

[29]. Tani Y., Yokota Y., Yayota M., \& Ohtani S. Automatic recognition and classification of cattle chewing activity by an acoustic monitoring method with a single-axis acceleration sensor. Computers an Electronics in Agriculture, vol. 92, 2013, pp. 54-65.

[30]. Deniz N.N., Chelotti J.O., Galli J.R., Planisich A.M., Larripa M.J., Rufiner H.L., \& Giovanin L.L. Embedded system for real-time monitoring of foraging behavior of grazing cattle using acoustic signals. Computers and Electronics in Agriculture, vol. 138, 2017, pp. 167-174.

[31]. Schirmann K., von Keyserlingk M.A., Weary D.M., Veira D.M., \& Heuwieser W. Validation of a system for monitoring rumination in dairy cows. Journal of Dairy Science, vol. 92, no. 12, 2009, pp. 6052-6055.

32]. Wilson R.P., \& McMahon C.R. Measuring devices on wild animals: what constitutes acceptable practice? Frontiers in Ecology and the Environment, vol. 4, no. 3, 2006, pp. 147-154.

[33]. Ungar E.D., Henkin Z., Gutman M., Dolev A., Genizi A., \& Ganskopp D. Inference of animal activity from GPS collar data on free-ranging cattle. Rangeland Ecology \& Management, vol. 58, no. 3, 2005, pp. 256-266.

[34]. McGavin S.L., Bishop-Hurley G.J., Charmley E., Greenwood P.L., \& Callaghan M.J. Effect of GPS sample interval and paddock size on estimates of distance travelled by grazing cattle in rangeland, The Rangeland Journal, vol. 40, no. 1, 2018, pp. 55-64.

[35]. Liu T., Green A.R., Rodríguez L.F., Ramirez B.C., \& Shike D.W. Effects of number of animals monitore on representations of cattle group movement characteristics and spatial occupancy. PloS one, vol. 10, no. 2, 2015 .

[36]. McGranahan D.A., Geaumont B., \& Spiess, J.W. Assessment of a livestock GPS collar based on an opensource datalogger informs best practices for logging intensity. Ecology and Evolution, vol. 8, no. 11, 2018, pp. 5649-5660.

[37]. de Weerd N., van Langevelde F., van Oeveren H., Nolet B.A., Kölzsch A., Prins H.H., \& de Boer W.F. Deriving animal behaviour from high-frequency GPS: tracking cows in open and forested habitat. PloS one, vol. 10, no. 6, 2015

[38]. Tofastrud M., Hegnes H., Devineau O., \& Zimmermann B. Activity patterns of free-ranging beef cattle in Norway. Acta Agriculturae Scandinavica, Section A - Animal Science, vol. 68, issue 1, 2018, pp. 39-47. 
39]. Meunier B., Pradel P., Sloth K.H., Cirié C., Delval E., Mialon M.M., \& Veissier I. Image analysis to refine measurements of dairy cow behaviour from a real-time location system. Biosystems Engineering, vol. 173, 2018, pp. 32-44

[40]. Larson-Praplan S., George M.R., Buckhouse J.C., \& Laca E.A. Spatial and temporal domains of scale of grazing cattle. Animal Production Science, vol. 55, no. 3, 2015, pp. 284-297.

[41]. Zhao K., \& Jurdak R. Understanding the spatiotemporal pattern of grazing cattle movement. Scientific reports, vol. 6, 2016.

[42]. Liao C., Clark P.E., Shibia M., \& DeGloria S.D. Spatiotemporal dynamics of cattle behavior and resource selection patterns on East African rangelands: evidence from GPS-tracking. International Journal of Geographical Information Science, vol. 32, no. 7, 2018, pp. 1523-1540.

[43]. Saint-Dizier M., \& Chastant-Maillard S. Methods and on-farm devices to predict calving time in cattle. The Veterinary Journal, vol. 205, no. 3, 2015, pp. 349-356.

[44]. Williams M.L., James W.P., \& Rose M.T. Fixed-time data segmentation and behavior classification of pasture-based cattle: Enhancing performance using a hidden Markov model. Computers and Electronics in Agriculture, vol. 142, 2017, pp. 585-596.

[45]. Sawalhah M.N., Cibils A.F., Hu C., Cao H., \& Holechek J.L. Animal-driven rotational grazing patterns on seasonally grazed New Mexico rangeland. Rangeland ecology \& management, vol. 67, no. 6, 2014, pp. $710-714$

[46]. Yoshitoshi R., Watanabe N., Kawamura K., Sakanoue S., Mizoguchi R., Lee H. J., \& Kurokawa Y. Distinguishing cattle foraging activities using an accelerometry-based activity monitor. Rangeland ecology \& management, vol. 66, no. 3, 2013, pp. 382-386.

47]. Thorup V.M., Munksgaard L., Robert P.E., Erhard H.W., Thomsen P.T., \& Friggens N.C. Lameness detection via leg-mounted accelerometers on dairy cows on four commercial farms. Animal, vol. 9, no. 10,2015, pp. 1704-1712.

[48]. Silper B.F., Madureira A.M.L., Kaur M., Burnett T.A., \& Cerri R.L.A. Comparison of estrus characteristics in Holstein heifers by 2 activity monitoring systems. Journal of dairy science, vol. 98 , no. 5, 2015, pp. 3158-3165

[49]. Bonk S., Burfeind O., Suthar V.S., \& Heuwieser W. Evaluation of data loggers for measuring lying behavior in dairy calves. Journal of Dairy Science, vol. 96, no. 5, 2013, pp. 3265-3271

[50]. Kienitz M.J., Heins B.J., \& Chester-Jones H. Growth, behavior, and economics of group-fed dairy calves fed once or twice daily in an organic production system. Journal of dairy science, vol. 100, no. 4, 2017, pp. 3318-3325.

[51]. Minnaert B., Thoen B., Plets D., Joseph W., \& Stevens N. Wireless energy transfer by means of inductive coupling for dairy cow health monitoring. Computers and Electronics in Agriculture, vol. 152, 2018, pp. 101-108.

[52]. Nadimi E.S., Søgaard H.T., \& Bak T. ZigBee-based wireless sensor networks for classifying the behaviour of a herd of animals using classification trees. Biosystems engineering, vol. 100, no. 2, 2008, pp. 167-176.

[53]. Reiter S., Sattlecker G., Lidauer L., Kickinger F., Öhlschuster M., Auer W., Schweinzer V., Klein-Jöbstl D., Drillich M., \& Iwersen M. Evaluation of an ear-tag-based accelerometer for monitoring rumination in D., Drillich M., \& Iwersen M. Evaluation of an ear-tag-based accelerometer
dairy cows. Journal of dairy science, vol. 101, no, 4, 2018, pp. 3398-3411.

[54]. Rutten C.J., Kamphuis C., Hogeveen H., Huijps K., Nielen M., \& Steeneveld W. Sensor data on cow activity, rumination, and ear temperature improve prediction of the start of calving in dairy cows. activity, rumination, and ear temperature improve prediction of the
Computers and Electronics in Agriculture, vol. 132, 2017, pp. 108-118.

[55]. Wolfger B., Timsit E., Pajor E. A., Cook N., Barkema H.W., \& Orsel K. Accuracy of an ear tag-attached accelerometer to monitor rumination and feeding behavior in feedlot cattle. Journal of animal science, vol. 93, no. 6, 2015, pp. 3164-3168.

[56]. Dutta R., Smith D., Rawnsley R., Bishop-Hurley G., Hills J., Timms G., \& Henry D. Dynamic cattle behavioural classification using supervised ensemble classifiers. Computers and Electronics in Agriculture, vol. 111, 2015, pp. 18-28.

[57]. Oudshoorn F.W., Cornou C., Hellwing A.L.F., Hansen H.H., Munksgaard L., Lund P., \& Kristensen T. Estimation of grass intake on pasture for dairy cows using tightly and loosely mounted di-and tri-axial accelerometers combined with bite count. Computers and Electronics in Agriculture, vol. 99, 2013, pp. $227-235$

[58]. Stone A.E., Jones B.W., Becker C.A., \& Bewley J.M. Influence of breed, milk yield, and temperaturehumidity index on dairy cow lying time, neck activity, reticulorumen temperature, and rumination behavior. Journal of dairy science, vol. 100, no. 3) 2017, pp. 2395-2403.
[59]. Nogueira G., Ajmone-Marsan P., Milanesi M., Zavarez L., Aguiar T.S., Sandre D., Maioli M.A., Ferreir G., Bispo G., Stabile S., Caputo R., Toyama C., Garcia J.F., \& Caputo, R. 1283 Understanding behavior patterns of cattle adaptation to heat stress. Journal of Animal Science, vol. 94, issue suppl_5, 2016, pp. patterns of

[60]. Marchesini G., Mottaran D., Contiero B., Schiavon E., Segato S., Garbin E., Tenti S., \& Andrighetto I. Use of rumination and activity data as health status and performance indicators in beef cattle during the early fattening period. The Veterinary Journal, vol. 231, 2018, pp. 41-47.

[61]. Greenwood P.L., Paull D.R., McNally J., Kalinowski T., Ebert D., Little B., Smith D.V., Rahman A., Valencia P., Ingham A.B., \& Bishop-Hurley G.J. Use of sensor-determined behaviours to develop algorithms for pasture intake by individual grazing cattle. Crop and Pasture Science, vol. 68, no. 12, 2017, pp. 1091-1099.

[62]. Schirmann K., Chapinal N., Weary D.M., Heuwieser W., \& Von Keyserlingk M.A. Rumination and its relationship to feeding and lying behavior in Holstein dairy cows. Journal of dairy science, vol. 95, no. 6 , 2012, pp. 3212-3217.

[63]. Knight C.W., Bailey D.W., \& Faulkner D. Low-Cost Global Positioning System Tracking Collars for Use on Cattle. Rangeland Ecology \& Management, vol. 71, no. 4, 2018, pp. 506-508.

[64]. Curtis A.K., Scharf B., Eichen P.A., \& Spiers D.E. Relationships between ambient conditions, thermal status, and feed intake of cattle during summer heat stress with access to shade. Journal of thermal biology, vol. 63, 2017, pp. 104-111.

[65]. Odadi W.O., Riginos C., \& Rubenstein D.I. Tightly Bunched Herding Improves Cattle Performance in African Savanna Rangeland. Rangeland Ecology \& Management, vol. 71, no. 4, 2018, pp. 481-491.

[66]. Samuels I., Cupido C., Swarts M.B., Palmer A.R., \& Paulse J.W. Feeding ecology of four livestock species under different management in a semi-arid pastoral system in South Africa. African Journal of Range \& Forage Science, vol. 33, no. 1, 2016, pp. 1-9.

[67]. Arcidiacono C., Porto S.M.C., Mancino M., \& Cascone G. Development of a threshold-based classifier for real-time recognition of cow feeding and standing behavioural activities from accelerometer data. Computers and electronics in agriculture, vol. 134, 2017, pp. 124-134.

[68]. Barker Z.E., Diosdado J.V., Codling E.A., Bell N.J., Hodges H.R., Croft D.P., \& Amory J.R. Use of nove sensors combining local positioning and acceleration to measure feeding behavior differences associated with lameness in dairy cattle. Journal of dairy science, vol. 101, no. 7, 2018, pp. 6310-6321.

[69]. Sprecher D.J., Hostetler D.E., \& Kaneene J.B. A lameness scoring system that uses posture and gait to predict dairy cattle reproductive performance. Theriogenology, vol. 47, no. 6, 1997, pp. 1179-1187.

[70]. Brown-Brandl T.M., \& Eigenberg R.A. Determination of minimum meal interval and analysis of feeding behavior in shaded and open-lot feedlot heifers. Transactions of the ASABE, vol. 58, no. 6, 2015, pp. 1833-1839.

[71]. Schieltz J.M., Okanga S., Allan B.F., \& Rubenstein D.I. GPS tracking cattle as a monitoring tool for conservation and management. African Journal of Range \& Forage Science, vol. 34, no. 3, 2017, pp. 173177.

[72]. Valls-Fox H., Chamaillé-Jammes S, de Garine-Wichatitsky M., Perrotton A., Courbin N., Miguel E., Guerbois C., Caron A., Loveridge A., Stapelkamp B., \& Muzamba M. Water and cattle shape habitat selection by wild herbivores at the edge of a protected area. Animal Conservation, vol. 21, no. 5, 2018, pp. 365-375.

[73]. Mahoney P.J., \& Young, J.K. Uncovering behavioural states from animal activity and site fidelity patterns. Methods in Ecology and Evolution, vol. 8, no, 2, 2017, pp. 174-183.

[74]. Mendes E.D.M., Carstens G.E., Tedeschi L.O., Pinchak W.E., \& Friend T.H. Validation of a system for monitoring feeding behavior in beef cattle. Journal of animal science, vol. 89, no. 9, 2011, pp. 2904-2910.

[75]. Curtis A.K., Scharf B., Eichen, P.A., \& Spiers D.E. Relationships between ambient conditions, therma status, and feed intake of cattle during summer heat stress with access to shade. Journal of thermal biology, vol. 63, 2017, pp. 104-111.

[76]. Oliveira B.R., Ribas M.N., Machado F.S., Lima J. A.M., Cavalcanti L.F.L., Chizzotti M.L., \& Coelho S.G. Validation of a system for monitoring individual feeding and drinking behaviour and intake in young cattle. Animal, vol. 12, no. 3, 2018, pp. 634-639.

[77]. Williams L.R., Fox D.R., Bishop-Hurley G.J., \& Swain D.L. Use of radio frequency identification (RFID) technology to record grazing beef cattle water point use. Computers and Electronics in Agriculture, vol. 156, 2019, pp. 193-202. 
78]. Bonk S., Burfeind O., Suthar V.S., \& Heuwieser W. Evaluation of data loggers for measuring lying behavior in dairy calves. Journal of Dairy Science, vol. 96, no. 5, 2013, pp. 3265-3271.

[79]. Michelot T., Langrock R., \& Patterson T.A. moveHMM: An R package for the statistical modelling of animal movement data using hidden Markov models. Methods in Ecology and Evolution, vol. 7, no. 11, 2016, pp. 1308-1315.

[80]. Calabrese J.M., Fleming C.H., \& Gurarie E. ctmm: an r package for analyzing animal relocation data as a continuous-time stochastic process. Methods in Ecology and Evolution, vol. 7, no. 9, 2016, pp. 1124-1132.

[81]. LaZerte S E., Reudink M.W., Otter K.A., Kusack J., Bailey J.M., Woolverton A., Paetkau M., de Jong A., \& Hill D.J. feedr and animalnexus. ca: A paired R package and user-friendly Web application for transforming and visualizing animal movement data from static stations. Ecology and evolution, vol. 7, no. 19,2017 , pp. $7884-7896$.

[82]. McLean D.J., \& Skowron Volponi M. A. Trajr: an R package for characterisation of animal trajectories. Ethology, vol. 124, no. 6, 2018, pp. 440-448.

[83]. Kranstauber B., Cameron A., Weinzerl R., Fountain T., Tilak S., Wikelski M., \& Kays R. The Movebank data model for animal tracking. Environmental Modelling \& Software, vol. 26, no. 6, 2011, pp. 834-835.

84]. Gurarie E., Andrews R.D., \& Laidre K.L. A novel method for identifying behavioural changes in animal movement data. Ecology letters, vol. 12, no. 5, 2009, pp. 395-408.

85]. Hunter J., Brooking C., Brimblecombe W., Dwyer R.G., Campbell H.A., Watts M.E., \& Franklin C.E. OzTrack--E-Infrastructure to Support the Management, Analysis and Sharing of Animal Tracking Data. In Proc. of the IEEE 9th International Conference on eScience, 2013, pp. 140-147.

[86]. Hirakawa T., Yamashita T., Tamaki T., Fujiyoshi H., Umezu Y., Takeuchi I., Matsumoto A., \& Yoda K. Can AI predict animal movements? Filling gaps in animal trajectories using inverse reinforcement learning. Ecosphere, vol. 9, no. 10, 2018.

[87]. Williams M.L., Mac Parthaláin N., Brewer P., James W.P. ., \& Rose M.T.A novel behavioral model of the pasture-based dairy cow from GPS data using data mining and machine learning techniques. Journal of dairy science, vol. 99 , no. 3, 2016, pp. 2063-2075.

\section{Информация об авторах / Information about authors}

Годофредо Рамон ГАРАЙ АЛЬВАРЕС получил степень бакалавра в области вычислительной техники в Высшем политехническом институте им. Хосе А. Эчеверрия, Гавана, Куба в 1994 году и степень доктора философии в университете Гранады, Испания в 2012 году. В настоящее время он является доцентом факультета информатики Камагуэйского университета, Куба. Его исследовательские интересы включают изучение проблем производительности в современных компьютерах, а также моделирование и оценку производительности.

Godofredo Ramón GARAY ALVAREZ received the B.E. degree in Computer Engineering from the ISPJAE, Havana, Cuba in 1994 and the Ph.D. degree in 2012, from the University of Granada, Spain. He is currently an Assistant Professor in the University of Camaguey's Faculty of Informatics, Cuba. His research interests include studying performance bottlenecks in current computers, and performance modelling and evaluation.

Хосе Альберто БЕРТОТ ВАЛЬДЕС в настоящее время является профессором кафедры репродукции животных в Университете Камагуэй, Куба. Он получил докторскую степень в области ветеринарии в Университете Камагуэй и Института наук о животных. Исследования Бертота сосредоточены на моделях прогнозов, направленных на улучшение организации и контроля воспроизводства систем молочного скота, а также на изучение влиянии заражения паразитами на производство молока крупного рогатого скота в провинции Камагуэй.

José Alberto BERTOT VALDÉS is currently a professor of of Animal Reproduction at the University of Camaguey, Cuba. Prof. Bertot received his doctoral degree in veterinary sciences from the University of Camagüey and Institute of Animal Science. Bertot's research focused on models for forecasts to improve the organization and control of the reproduction of dairy cattle systems and the effects of parasite infestation in the milk production of cattle of the province of Camagüey.
Карина ПЕРЕС-ТЕРУЭЛЬ в настояшее время является директором по инновациям Открытом университете для взрослых, Доминиканская Республика. Она получила степень $\mathrm{PhD}$ в Университете компьютерных исследований на Кубе. Научные интересы включают нейрообразование, нечеткие когнитивные карты, программную инженерию, принятие групповых решений.

Karina PÉREZ-TERUEL is currently a Director of Innovation at Open University for Adults, Dominican Republic. She received her PhD at University for Informatics Science, Cuba. Scientific interests include neuroeducation, fuzzy cognitive maps, software engineering, group decision making. 